Article

\title{
The Local Governance of Arrival in Leipzig: Housing of Asylum-Seeking Persons as a Contested Field
}

\author{
Franziska Werner ${ }^{1, *}$, Annegret Haase ${ }^{2}$, Nona Renner ${ }^{3}$, Dieter Rink ${ }^{2}$, Malena Rottwinkel ${ }^{1}$ and Anika Schmidt ${ }^{2}$ \\ ${ }^{1}$ Faculty of Architecture and Urbanism, Bauhaus-Universität Weimar, 99423 Weimar, Germany; \\ E-Mails: franziska.werner@uni-weimar.de (F.W.), malena.rottwinkel@uni-weimar.de (M.R.) \\ 2 Department of Urban and Environmental Sociology, Helmholtz Centre for Environmental Research, 04318 Leipzig, \\ Germany; E-Mails: annegret.haase@ufz.de (A.H.), dieter.rink@ufz.de (D.R.), anika.schmidt@ufz.de (A.S.) \\ ${ }^{3}$ Faculty of Arts, Humanities and Social Science, University of Technology Dresden, 01069 Dresden, Germany; \\ E-Mail: nona.renner@tu-dresden.de \\ * Corresponding author
}

Submitted: 31 July 2018 | Accepted: 13 November 2018 | Published: 20 December 2018

\begin{abstract}
The article examines how the German city of Leipzig governs the housing of asylum seekers. Leipzig was a frontrunner in organizing the decentralized accommodation of asylum seekers when adopting its accommodation concept in 2012. This concept aimed at integrating asylum-seeking persons in the regular housing market at an early stage of arrival. However, since then, the city of Leipzig faces more and more challenges in implementing the concept. This is particularly due to the increasingly tight situation on the housing market while the number of people seeking protection increased and partly due to discriminating and xenophobic attitudes on the side of house owners and managers. Therefore, we argue that the so-called refugee crisis of 2015-2016 has to be seen in close interaction with a growing general housing shortage in Leipzig like in many other large European cities. Furthermore, we understand the municipal governing of housing as a contested field regarding its entanglement of diverse federal levels and policy scales, the diversity of stakeholders involved, and its dynamic change over the last years. We analyze this contested field set against the current context of arrival and dynamic urban growth on a local level. Based on empirical qualitative research that was conducted by us in 2016, Leipzig's local specifics will be investigated under the umbrella of our conceptual framework of Governance of Arrival. The issues of a strained housing market and the integration of asylum seekers in it do not apply only to Leipzig, but shed light on similar developments in other European Cities.
\end{abstract}

\section{Keywords}

accommodation; arrival; asylum seekers; Germany; governance; housing; Leipzig; refugees

\section{Issue}

This article is part of the issue "European Cities Planning for Asylum", edited by Frank Eckardt (Bauhaus-Universität Weimar, Germany).

(C) 2018 by the authors; licensee Cogitatio (Lisbon, Portugal). This article is licensed under a Creative Commons Attribution 4.0 International License (CC BY).

\section{Introduction}

Three years after the "long summer of migration" (Kasparek \& Speer, 2015), the situation regarding the arrival of asylum seekers in Germany has changed profoundly. The welcoming atmosphere of 2015, the challenge of the European border regime through the movements of people, and the "de facto suspension of the
Dublin system" (Ataç, Kron, Schilliger, Schwiertz, \& Stierl, 2015) have faded into the background. The process of change becomes evident through the reinforcement of asylum laws, further attempts to tighten the existing Common European Asylum System for refugees and residence requirements, deportations, and political and media discourses focusing on refugees and migration as "a problem". 
The local level is the newcomers' place to arrive and live, and political-administrative actors are setting the formal framework for their social and economic participation in society. Many medium and large cities in particular face a considerable in-migration of assigned asylum seekers and recognized refugees in Germany (Bundesinstitut für Bau-, Stadt- und Raumforschung [BBSR], 2017; Hallenberg, 2017) and therefore, urban planning is in demand to deal with the different aspects of arrival and integration. Here, housing is a fundamental first step in the arrival process and a precondition of further long-term integration. Within the last years, several studies or databases have been established that enable a comparative perspective in Europe (see Asylum Information Database, 2015; European Commission, 2018; International Federation for Housing and Planning [IFHP], 2016). However, studies that focus on the housing issue remained few among mushrooming publications on asylum and refugees.

This article focuses on the possibilities and challenges of municipal administration enabling asylum seekers to find a place to live within the regular housing market in Germany. Therefore, it discusses how accommodation and housing of asylum seekers are organized and governed in German cities. In particular, it assesses whether the housing of asylum seekers can be described as a new policy field for urban planning and policy and to what extent it represents a contested field characterized by challenges and interest conflicts between the involved actors.

The article will present the local strategies of planning and providing housing for asylum seekers in the city of Leipzig a municipality that is located in Eastern Germany, former GDR, and shows an atypical development for the region. When publishing a concept that aimed at integrating asylum seekers in the regular housing market at an early stage of arrival in 2012, the city of Leipzig was a pioneer in organizing so-called decentralized accommodation. Right from the start, the municipality faced challenges in implementing this concept and the situation was aggravated in the context of post-2015 developments. Using the example of the city of Leipzig, with its almost 600,000 inhabitants in June 2018, this article represents valuable information on how the arrival of asylum seekers is handled in a large German city confronted with an increasingly contested housing market.

While conceiving housing as a contested field, the article outlines the bureaucratic regulations and requirements municipalities and asylum seekers face, describes the insufficient support and discrimination during the search for an apartment, and takes the structural influence of the local housing market into account. Therefore, the authors unfold the federal structures and regulations and show that this Governance of Arrival (henceforth GoA) has consequences for planning processes dealing with the housing of asylum-seekers on a local level (Section 2). After introducing the context of Leipzig (Section 3), we discuss our empirical findings with regard to this conceptual outline. Our findings are based on empirical studies carried out in 2016 and include an analysis of different (municipal) documents as well as qualitative interviews conducted with representatives of the municipality and stakeholders from civil society and the housing market (Section 4). The conclusion (Section 5) summarizes the responses to our research objectives and provides an outlook with respect to the further development, re-embedding Leipzig into a larger context.

\section{GoA: A Conceptual Framework}

The structure of our analysis is guided by two conceptual ideas. On the one hand, we develop a conceptual framework that we call GoA, which includes all rules, governance structures and involved groups of actors that deal with the arrival of asylum seekers. On the other hand, we will focus in particular on the policy field of accommodation and housing in a context of demand surplus and lack of low-price housing, as it is typical for many large cities in Germany and other European countries or beyond. Our intention is to combine these two perspectives in order to: 1) understand their interrelations and 2 ) to show how general features of housing market conditions and development, as well as the specifics of the arrival and the situation of asylum seekers as a group of newcomers on German urban housing markets, are leading to new challenges for local actors.

Across Europe, the responsible authorities, systems, and conditions of accommodation and housing for asylum seekers are variegated, e.g., regarding the actors involved, such as state and local authorities, NGOs, private companies, and the types of facilities (see European Migration Network [EMN], 2014). In most EU-member states, asylum applicants are accommodated in initial accommodation facilities during the (first steps of the) asylum procedure. Later, the majority of states makes use of more or less open collective facilities or community accommodation, while a certain share of EU members (additionally) make use of private houses or flats (e.g., Austria, Czech Republic, France, Hungary, Italy, Spain, Sweden, United Kingdom; see EMN, 2014, p. 14). Germany is the only country in the European Union where regional or local authorities carry the financial and executive responsibility for reception facilities. In other member countries, a state authority has full responsibility for the implementation and day-to-day running or, as is the case in Austria, Belgium, Cyprus, Italy, and Sweden, shares it with local authorities (EMN, 2014, p. 15).

The German asylum system is based on a complex interplay of laws and regulations on the EU, federal, state, and municipal level (Aumüller, 2018; Schammann, 2015). This multilevel system defines responsibilities and affects inter alia the types of accommodation during the asylum process and the possibility for asylum seekers to enter the regular housing market. After entering the country, asylum seekers are sent to initial reception centers where they have to stay for a maximum of six months. 
The distribution among the 16 federal states is based on a quota system, called Königstein Key, which takes into account the state's tax revenue and the number of inhabitants and thus tries to share the efforts and expenditures of reception. The federal states are obliged to supply a sufficient number of accommodations in these initial reception centers and can pass laws and guidelines on issues such as housing, freedom of movement, and the further distribution of asylum seekers within the federal state. From the initial reception centers, asylum seekers are allocated to districts and county boroughs and the local authorities are in charge of further accommodation until the end of the asylum procedure.

The federal states are partially covering the arising costs while the specific forms of financing differ widely and mainly do not compensate for the expenditures of the local administration (Aumüller, 2018, p. 181). For asylum seekers, the municipality they are assigned to represents their obligatory place of residence until the end of the asylum procedure. Within the German asylum system, the municipalities have a "hybrid identity" (Schammann, 2015, p. 28): On the one hand, they have to fulfill laws and obligations at higher federal levels; on the other hand, they are authorized to manage their own affairs which opens up a certain scope of action regarding the local reception of asylum seekers and refugees. According to federal law, municipalities have the duty to host a certain number of asylum seekers and should provide a respective number of places in so-called community accommodations.

While these shared accommodations are still the regular case in most municipalities, a rising number of administrations use their scope of action to implement alternative accommodation options. Since around the year 2000, a couple of municipalities (e.g., Berlin, Cologne, Dresden, Leipzig and Leverkusen) have introduced accommodation concepts that follow the idea of so-called decentralized housing (Aumüller, 2018, p. 184; Wendel, 2014 , p. 10). Different rationalities, such as humanitarian vs. economic are shaping these transitions. The concepts are the outcome of political and public debates and struggles about the exclusionary and often inhumane living conditions in large accommodation centers combined with general uncertainty and psychological pressure during the asylum procedure (Aumüller, 2018, p. 185; Eckardt, 2018). According to Fontanari (2015), these large facilities lead to a condition of time suspension, non-belonging, and in-betweenness affecting asylum seekers' sense of self and posing a "threshold of citizenship". The transition from state-organized accommodation to housing market access can be seen as one of several transitions in different realms of civil and social rights that refugees undergo when changing between legal statuses during the asylum-seeking process (El-Kayed \& Hamann, 2018, p. 144). Furthermore, decentralized housing instead of large, shared accommodation centers does not offer a clearly visible target and symbol for antirefugee protest and racist attacks.
Still, the interpretation and notion of decentralized accommodation differs widely between the municipalities and may relate to the possibility of living in a flat rented by the municipality, renting one's own flat, or to a procedure where people are assigned to a room within a flat or housing unit within a larger shared accommodation (Aumüller, 2018, pp. 186-187). The upper limit of rent is not federally regulated but set by the social welfare office in charge. In general, the rates gear towards the local rates of the covered costs for accommodation of other beneficiaries like unemployed persons. In December $2017,44,5 \%$ of all asylum-seeking persons receiving allocations in Germany have been living in so-called decentralized accommodation (Statistisches Bundesamt, 2018a), but it can be assumed that some federal states subsume smaller types of collective accommodation under "decentralized" housing as well (Mierswa, 2016, p. 8). After recognition of a right to asylum, refugees are entitled to receive the regular state welfare and have to move into a flat on their own if they had lived in community accommodation previously.

In reality, in municipalities allowing decentralized housing and refugees who had to move out of the municipal accommodation after obtaining a residence permit, asylum seekers essentially have to overcome many of barriers. The dependence on social welfare and a low share of affordable housing in many German cities make it difficult to find flats to rent and lead to a concurrence with other beneficiaries of social welfare or even a "black market" for subleasing and renting (Aumüller, 2015, pp. 59, 113-114; BBSR, 2017, pp. 7-8). Asylum seekers, as additional demanders on the evermore-contested housing markets in many German cities aggravate the problem of demand surplus, primarily in the low-pricesegment. In the struggle for affordable apartments, people who are perceived as "foreigners" and/or receive state support particularly face considerable discrimination in the housing market (Federal Anti-Discrimination Agency [FADA], 2016).

\subsection{Towards GoA: Reception of Asylum Seekers as a New Municipal Policy Field}

In the last decades, the municipalities' social and housing policies did not include asylum seekers or refugees as a target group. Often, even integration measures for migrants deliberately excluded both groups. As this political disintegration collided with their real-life presence and the rising number of arrivals at least since 2012 , local politics and administration had to find new approaches towards the social and integration-related needs (Aumüller, 2018, pp. 182-183). The reception of large numbers of asylum seekers, especially around 2015 , challenged the municipalities' policies and strategies in an unforeseen way. New ways of problem solving had to be found and cooperation with nongovernmental-actors received a much larger importance, as it was enlarged, intensified, or adapted to the needs 
of the situation. Many ways of cooperation had to be established.

These changes in policies and approaches in asylum seekers' reception on the local level can be interpreted as the bottleneck within a wider change of urban governance and planning. Financial constraints and the need to act more efficiently urge municipalities to adjust their modes of decision making, service provision, and designing of urban policies towards new forms of complex urban governance with a multitude of actors and networked forms of coordination. In this context a "governance-beyond-the-state" (Swyngedouw, 2005) emerged:

Which give[s] a much greater role in policy-making, administration, and implementation to private economic actors on the one hand and to parts of civil society on the other in self-managing what until recently was provided or organized by the national or local state. (Swyngedouw, 2005, p. 1992)

"Governance arrangements" are, according to Swyngedouw (2005), an outcome of these processes and involve a more or less "horizontal interaction among presumptive equal participants without distinction between their public or private status, while these actors are described as independent, but at the same time interdependent actors" (Swyngedouw, 2005, p. 1994). New institutions emerge, and actors are empowered, but presumably innovative arrangements "are fundamentally Janus-faced, particularly under conditions in which the democratic character of the political sphere is increasingly eroded by the encroaching imposition of market forces that set the 'rules of the game'" (Swyngedouw, 2005, p. 1993).

The developments in the field of local asylum seekers' reception and accommodation can be discussed with this perspective as many municipalities were relying on new forms of cooperation and networking between the state, civil society, charities, and private-sector actors to organize further shared accommodation, acquire apartments, and provide necessary support regarding formal and social aspects related to housing. Volunteers provided a crucial contribution to fulfilling initial municipal tasks of local refugee reception and administrations try to foster and bind this resource by implementing networks and coordinative as well as financial support for civic engagement (Gesemann \& Roth, 2016). While the German "welcome culture" and civil society's contribution to the "humanitarian challenge" had been praised in the media and by politicians, other voices point to the fact that the reception of refugees has followed policies of deterrence. In addition, the reduction in reception infrastructure in previous years and civil society's activities have served as a compensation for structural weaknesses or even concealed the failure of authorities (see Hinger, 2016; Karakayali \& Kleist, 2016).

Based on the concept of "cultural landscapes" as modes of ordering the world (Mitchell, 2002, p. 381),
Hinger, Schäfer and Pott (2016) develop a notion of a "landscape of asylum" as a socio-spatial construct that emerges out of the multi-level negotiation process regarding the accommodation of asylum-seeking persons. They conceive this landscape of asylum as a "placespecific process-structure and socio-political order which encompasses much more than local politics" and is constantly being reproduced and reshaped (Hinger et al., 2016, p. 453). Informed by this notion of the local reception of asylum-seeking persons as a place-specific process structure, we adopt the perspective of a local GoA as a specification of urban governance with regard to the reception of asylum seekers, as the evolved socio-spatial arrangements are place-specific and temporal, shaped and reproduced by the interplay and interdependencies of the local actors.

In this article, GoA is conceived as all formal and informal framings of local refugee reception, thus encompassing the municipal tasks within the federal asylum system as well as the municipalities' scope of action regarding policies related to further social and economic integration and possible participation into (urban) society. This also relates to the administrations' reactions to changing demands. The extraordinary circumstances in 2015 intensified the need to form a new municipal field of action that still lives on today and involves diverse forms of cooperation with non-governmental actors. Either the impetus for a governance change was an active willingness of municipalities to create an inclusive and welcoming arrival scenario, or they were partially pushed by their legal tasks and the mere presence of asylum seekers and refugees to find solutions-or both at the same time.

Linking the two theoretical framing landscapes of asylum and GoA seems to be a fruitful way to focus on the planning and political structure of the arrival process. Arrival processes in the center of reflection serve the purpose of scrutinizing the preconditions of integration aspects.

We identify three dimensions of a GoA: 1) the development of a new policy field within the hybrid identity of municipalities in the last couple of years; 2 ) the need to include new actors in the implementation process and to (re-)develop governance arrangements; and 3) a dynamic process regarding time, space, and action. As such, they together capture structural and planning aspects of the arrival situation.

In this article, we will focus on the issue of housing as a core issue of reception and as an important condition for a long-term integration process. Thus, we concentrate on the specific complex situation of asylum seekers and depict the state-dominated processes with regard to housing and accommodation, a field shaped by different laws and practices of actors involved on various federal levels. Thus, we conceive this field as highly contested as it is particularly characterized by negotiation, conflict, and often-contradictory logic. This already becomes obvious in the fact that at federal and state level, migration is often discussed within the framework of regulatory is- 
sues while, at the local or municipal level, migration issues are mainly discussed related to practical implementation or (long-term) integration. This general cleavage between federal levels may also affect how asylum seekers are accommodated (central vs. decentral).

\section{Urban Development and Asylum in the City of Leipzig}

Leipzig is a post-socialist city and has gone through different, even extreme phases of development since the German reunification. Like most cities in Eastern and Central Europe, it was an ethnically very homogeneous city in the state socialist phase; the proportion of foreigners before 1989 was around 3\%. The transformation period of the 1990s was characterized by deindustrialization and a massive shrinkage. The city lost more than 100,000 inhabitants or about $20 \%$ of the 1989 population due to emigration, suburbanization, and declining birth rates. At the same time, migrants from different countries, especially from the former Soviet Union and Poland, came to Leipzig on a yearly basis of 1-2,000 people (Philipps \& Rink, 2009, p. 402), a typically migrant quarter started to develop in Leipzig's inner east. When Leipzig saw moderate growth and reurbanization in the 2000s, immigration from abroad initially remained low, as unemployment was very high and jobs hard to get. Until the 2010s, the diversity of the population in Leipzig continuously increased: in $2015,8 \%$ were foreigners (with a non-German passport) and $12 \%$ of the population had a migration background. Driven by several large industrial and service investments in the 2000s, Leipzig entered a phase of dynamic growth in the 2010s; during recent years, in-migration increased to over 10,000 people per year (approx. 2\%). Because of the crisis in Southern Europe, immigration from abroad has increased and accounts for one third. The total share of migrants rose to more than 14\% (foreigners 9,5\%) in 2017 and shows the highest rates within the State of Saxony, but still rates low when compared to the national level $(10,8 \%$ foreigners, $22 \%$ people with a migrant background; see Statistisches Bundesamt, 2018b; Stadt Leipzig, 2018b).

The share of foreigners also rose due to an increasing number of asylum seekers that were assigned to Leipzig in the last couple of years. As described above, the German asylum system is characterized by the interplay of complex multi-level regulations and tasks. While the State of Saxony has to receive $5 \%$ of the asylum seekers within Germany according to the Königstein Key, Saxon regulations foresee that Leipzig is obliged to take in $13 \%$ of those arriving in this federal state (Sächsische Staatskanzlei, 2018). Figure 1 shows the intensive variation of this assigned number of asylum seekers, while the state share percentage has almost stayed the same in the last years.

The arrival of asylum seekers has thus reached annual numbers that had never been the case before. At the beginning of the 1990s, Leipzig firstly received asylum seekers, initially mainly several hundred persons from former Yugoslavia and Romania. They had to live in mass accommodation houses on the outskirts of the city and had practically no contact with the German population. However, from the mid/end of the 1990s, as a result of shrinkage and housing oversupply, it was relatively easy for them to move into one of the many empty flats and rents were affordable (Grossmann, Arndt, Haase, Rink, \& Steinführer, 2015). However, only recognized asylum seekers whose long-term integration was supported could take this opportunity.

Due to a city council resolution in 2010 , the municipality decided to restructure the accommodation process of asylum seekers during their asylum procedure and Leipzig's mayor was authorized "to develop a concept for a largely decentralized accommodation" (Stadt

\section{Number of Asylum Applicants in the city of Leipzig}

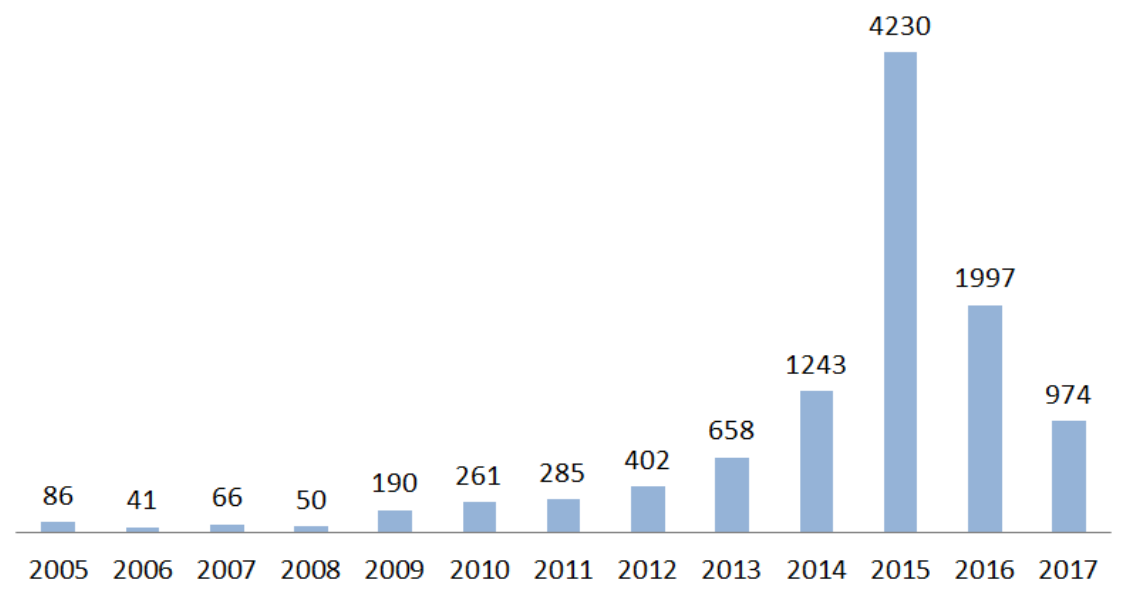

Figure 1. Asylum applicants that were assigned to the city of Leipzig. Source: Office for Social Affairs of the city of Leipzig (Stadt Leipzig, 2018a, p. 2) 
Leipzig, 2010). At that time, only two municipal accommodation centers with high capacities existed and the resolution intended to limit the capacity of newly built centers to a maximum capacity of 50 persons. Because of the increasing number of asylum seekers since 2009 and difficulties in finding additional locations for shared accommodation, the concept could not be completed until 2012.

The Leipzig accommodation concept Housing for Recipients of the Asylum Seekers Benefits Act (henceforth accommodation concept) foresees a three-step procedure for accommodation (see Figure 2). After the stay in Saxony's initial reception centers, asylum seekers should live in shared municipal accommodation with capacities for 150 to 200 people for a period of six months up to one year. After that, they should be assigned to smaller shared accommodation for about 100 people. Here, according to the municipal concept, the asylum seekers get prepared to live in own apartments and receive assistance in finding one. As a third stage, the model provides decentralized accommodation, defined as living in self-selected social units in a flat, which is independently rented by the inhabitant. Only in exceptional cases, the city of Leipzig provides housing for asylum seekers in flats rented by the municipality. The accommodation concept argues that this decentralized accommodation facilitates the integration of asylum seekers into urban society and enables privacy and self-determination. As the possibility to live in flats instead of shared accommodation is not foreseen as a regular form of accommodation by the legislator during the asylum procedure, the city of Leipzig is obliged by the State of Saxony to examine each individual case and decide whether the person in question may move from shared to decentralized accommodation. Prerequisites for the move are humanitarian or medical reasons and a specific application to live in a private flat filled out by the asylum seeker and approved by the social welfare office (Stadt Leipzig, 2012, p. 6). Before a legal opinion questioned the lawfulness of this praxis in December 2017, also called a social prognosis, a valuation of the conduct and personal situation of the asylum seeker by a social worker was part of this process (Leipziger Internetzeitung, 2017). Furthermore, decentralized accommodation has to be less expensive than housing in shared accommodation (Stadt Leipzig, 2012, p. 8). Currently, a single-person household may spend 215.50 EUR on basic rent (Stadt Leipzig, 2018d).

The support by social workers is foreseen at each step of the accommodation process and the municipality provides a certain financial support for some registered associations that support asylum seekers with regard to daily life issues such as the asylum procedure, work or educational issues, language courses, or housing related aspects.

While drafting the accommodation concept, it also became obvious that there would be difficulties to implement it as the municipality had problems finding enough low-cost apartments whose owners were willing to cooperate, so the accommodation concept needed to be updated the following year. Already at the time of updating, many asylum seekers could not find suitable apartments to rent (Stadt Leipzig, 2013, p. 2). Furthermore, according to the concept, the shared accommodation and individual apartments should ideally be dispersed over the whole city due to aspirations of social mixing within neighborhoods and individual housing estates.

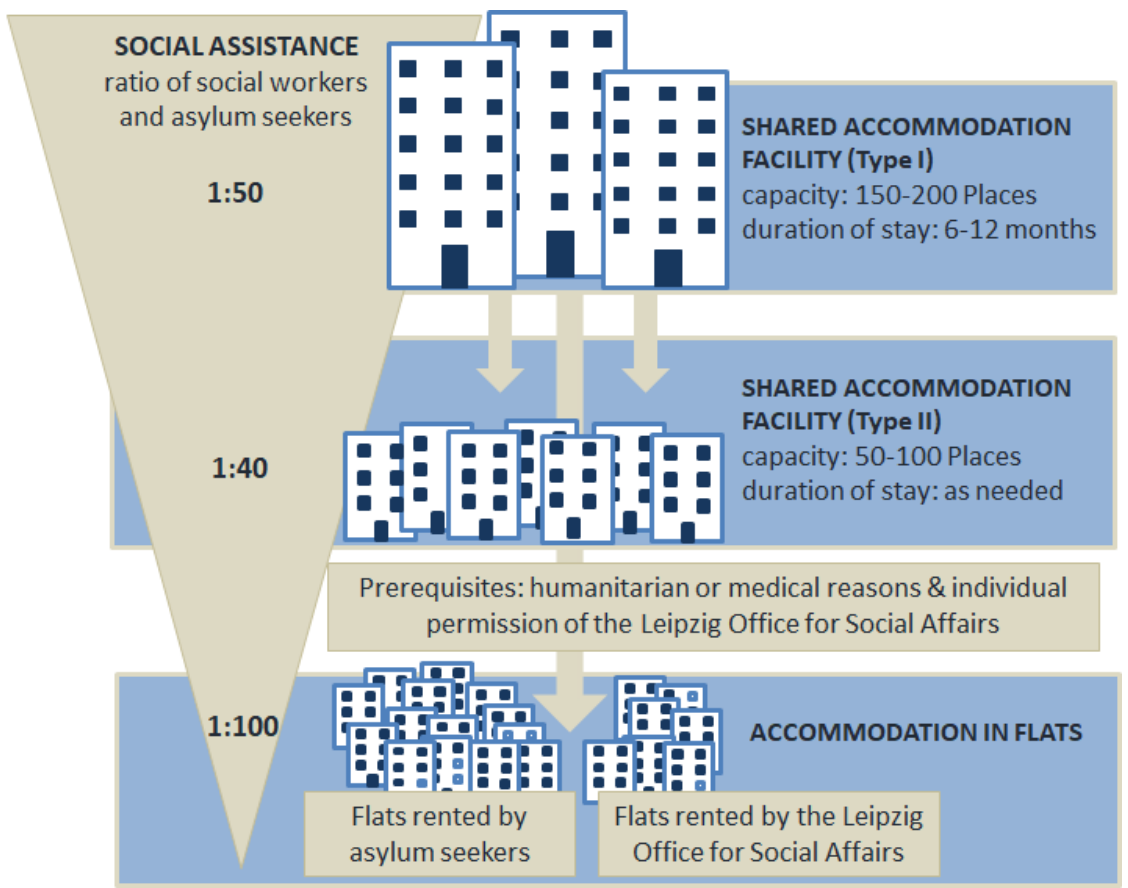

Figure 2. Leipzig's three-step accommodation system for asylum seekers, including quotas for social assistance. Source: based on Stadt Leipzig (2012). 
Since then, the integration possibilities of the Leipzig housing market declined steadily, especially in the lower price segment and few remaining opportunities can be found in a few selected neighborhoods.

In reaction to the rapidly increasing number of asylum seekers during 2015 (see Figure 1), as in many other German municipalities, emergency accommodation centers were opened or extended in Leipzig. Asylum seekers were hosted in a wide range of shelters: in regular tenements, partially with completed residential units, in non-residential buildings, such as an exhibition hall or a hardware store, as well as in temporary shelters, such as tents and containers. While the stay in large community accommodations should be limited to the time of the asylum application procedure, a large number of people in these facilities already received state welfare and thus should actually have moved into their own apartments.

Landlords who refuse to rent their flats to asylum seekers and refugees aggravate the general housing shortage. The reasons not to rent range from uncertainties regarding the tenancy due to ongoing asylum procedures or limited residence permits, to a housing management that tries to avoid "overcharged" houses as well as openly expressed racist attitudes. As a result, the rate of accommodation in flats reached a low point in 2015: while drafting the accommodation concept, more than $60 \%$ of all asylum seekers were accommodated in flats (Stadt Leipzig, 2012, p. 11) during 2015-2016. The share ranged from under one third to just over $43 \%$.

From 2010 onwards, due to increasing immigration and decreasing vacancies, the situation on Leipzig's housing market started to change (Stadt Leipzig 2015). The previously high vacancy rates are vanishing, rents have in- creased and the housing market's characteristics turned from supply to demand surplus in the second half of the 2010s. Now, recipients of social welfare and lowincome earners can no longer provide themselves with cheap housing; migrants, asylum seekers, and refugees are additionally excluded by xenophobic reservations or racist attitudes (Budnik et al., 2016). The changing housing market is challenging the decentralized approach of the Leipzig accommodation concept even more.

\section{Discussion: Housing as a Contested Field within GoA}

The aforementioned developments and structural changes regarding the accommodation and housing of asylum seekers can be described as features of the local GoA. Hereinafter, we will shed light on the current actors involved in the GoA, their interactions and cooperation, and existing challenges and conflicts to reveal that Leipzig's housing market can be seen as a contested policy field in this regard.

As Figure 3 shows, GoA is a complex municipal field of action. The levels of federal and state government, with their laws and regulations, and the provision of financial and human resources, have a decisive influence on the GoA, even if they are not directly represented in the governance structures at the local level.

The Office for Social Affairs and its department for migrant help are the administrative units in charge of the basic supply for asylum seekers and their housing. It is politically controlled by the City Council and depends on cooperation with other states, intermediary and civil society actors such as associations, welfare organizations, and housing market actors to fulfill these tasks. Some

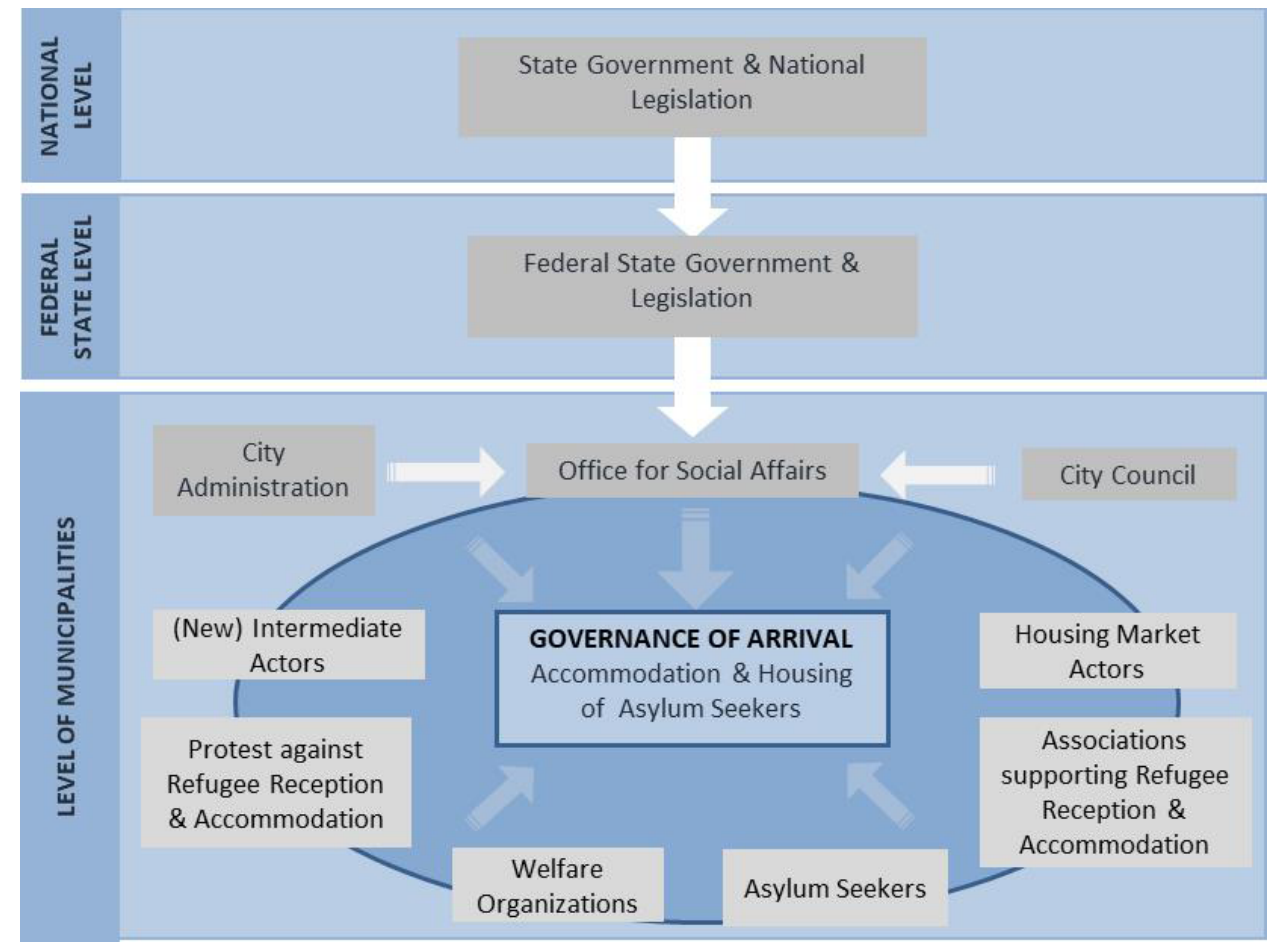

Figure 3. Governance of arrival. Source: authors' own elaboration. 
of this cooperation has a longer history, some of which built on newly established actors or a new appearance of these actors in the field of refugee reception. Due to the developments of recent years, the policy field of accommodation was reformed and restructured within the city's administration.

The housing of asylum seekers can thus be regarded as one of several social welfare issues that the Office of Social Affairs is in charge of. The core formal task within the GoA is to accommodate the asylum seekers that the Federal State of Saxony assigns to live in Leipzig. In other municipalities, these tasks are often on the agenda of the regulative authorities. Through the implementation of the Leipzig accommodation concept in 2012, this task should be fulfilled with a specific proclaimed willingness to humanitarian housing and the city of Leipzig took advantage of the respective legal possibilities, thus individually framing the GoA. Before the interdepartmental working group Asylum was established in 2015, the Office for Social Affairs had to deal with finding, planning, and implementing shared accommodations and flats rented by the city without the respective planning capacities and the relevant position within the municipality administration in general (see Figure 3). This task was and is especially difficult because of the increasing affordable housing shortage. In addition to personnel restrictions, the Office of Social Affairs faced several core challenges implementing decentralized housing for asylum seekers. First, it had to negotiate the implementation of the Leipzig accommodation concept as federal state actors interpreted it as contradicting Saxon law, second asylum seekers' access to the housing market, and also the administrative unit's contact to housing market actors was more difficult and complex than expected and, thirdly, the supply of affordable flats has been constantly diminished since the situation on the Leipzig housing market became tenser. Overall, this shapes the contested field of housing in Leipzig.

According to information from the Leipzig Office for Social Affairs, asylum seekers have been accommodated not only in shared accommodation but also in apartments since 2004, thus, already before the Accommodation concept from 2012. The State of Saxony rejected this municipal practice following a degree of the Saxon Ministry of the Interior from 2001 which allowed a decentralized accommodation in exceptional cases only. Consequently, the drafting and implementation of Leipzig's accommodation concept, which foresaw a constant rise in the percentage of asylum seekers living in flats, was accompanied by strong critics from the federal State of Saxony. This situation changed only in 2014 when the State of Saxony released an own accommodation concept including a commitment to accommodate some groups of asylum seekers in a decentralized way, e.g. in own flats or housing units.

Since the adoption of Leipzig's accommodation concept in 2012, the situation in the city has changed profoundly as the city government and administration were willing to overcome political, structural and organizational barriers in order to be able to implement decentralized, i.e. own flat-based housing. In doing so, the human rights perspective was paid attention to, and, at the same time, an additional option for accommodating people in the time when rising numbers of people were assigned to the municipalities in Saxony in 2015/16 could be provided.

When looking at civic society, we find a complex situation with competing and contrasting attitudes as well (see Figure 3). On the one side, there was a considerable protest against refugee reception and accommodation within the city of Leipzig. The reception of refugees was questioned, in principle, by the right-wing populist movement LEGIDA (a pendant to the more well-known PEGIDA movement that started to act in 2014 in Dresden) and the right-wing populist party AfD (Alternative for Germany) in Leipzig as in many other places across Germany. Smaller initiatives specifically opposed community accommodations in certain neighborhoods and in one case prevented the housing of asylum seekers and refugees in a singlefamily housing estate. On the other hand, there is a multitude of associations and initiatives that support or even demand the reception of refugees in Leipzig. These initiatives support asylum seekers and refugees on a daily basis, bring them in touch with longer-term inhabitants, and foster their social participation in urban society.

While associations and activist groups have been influencing political actors and policies regarding the housing of asylum seekers for many years, and new governance structures have evolved that are building on respective resources. Thus, the intensity and modes of interference have become more diverse since the drafting and implementation of the Leipzig accommodation concept, considering the high number of incoming asylumseeking persons since 2014. The aim of Leipzig's decentralized accommodation concept was to clearly state that to live in an own flat should be considered as the only humane option to provide (longer-term) housing for refugees. To reach this aim, the concept was elaborated based on networking activities including various actors. This process was accompanied by long-term protests of civic society associations pointing to the rights of refugees and making their situation and needs visible. The Refugee Council, an association that aimed at raising awareness regarding the situation of refugees in the city of Leipzig, took an active part in the drafting of the concept and played a role in its implementation when offering social consultation for asylum seekers living in own flats. On the contrary, the civic association for human dignity acts as a critical observant questioning the necessity for the shared accommodation steps within the concept.

The Contact Point Housing initiative (Kontaktstelle Wohnen) can be interpreted as a governance arrangement (Swyngedouw, 2005) within the local GoA. It serves as an example for the active involvement of non-state actors in fulfilling municipal tasks as its activities are explicitly dedicated to supporting asylum seekers and refugees 
with finding a flat and dealing with the bureaucratic process of state support payment for housing. The persons involved, partly from the Association for Human Dignity, saw an urgent need to create new support structures and could rely on networks and experience in housing issues through their voluntary engagement (for refugees and social aspects of Leipzig's housing market in general). Funding from the city of Leipzig and other sources allowed them to open an office in 2015 and begin to get in touch with housing market actors to create awareness for the issue of refugee housing. A central strategy was to manage a pool of volunteers to support people as housing peers to overcome barriers based on language and structural knowledge of how to navigate through the process of house seeking. As their approach was unique in Germany at that time, they soon gained wide political and public attention. The task of the Contact Point Housing was to establish a bridge between the state authorities in charge of the accommodation of asylum seekers or refugees and house owners, housing associations, and enterprises. They should support people to get their own rent contracts, thus helping them to move out of shared accommodation facilities. As a civil society actor, the Contact Point Housing builds a partnership with state actors and gets involved with their unique resources and personal commitments. They partially fulfill municipal tasks as they support the municipality to implement the Leipzig accommodation concept. Still, the dependence on funds is creating the necessity to negotiate the goals and scope of actions and makes it difficult to plan for the longer term. Furthermore, the most obvious challenge for their work has recently been the tight housing market in Leipzig.

The accommodation concept is a planning instrument for asylum seekers' integration into the housing market, but the recent reality shows that flats that meet the financial constraints of state welfare can only be found in certain areas of the city, thus causing residential segregation instead of preventing it. An analysis of housing offers for the year 2017 has shown that only 3\% of the offered flats in Leipzig are suitable for asylum seekers. These apartments are located almost exclusively in the prefabricated housing areas in the western and eastern parts of the city (Rink, Schneider, \& Haase, 2018). This increases ethnic segregation, which is higher in East German cities such as Leipzig, with a relatively lower proportion of foreigners than in West German cities (Helbig \& Jähnen, 2018, p. 33). The tense situation regarding asylum seekers' search for apartments became particularly apparent when the municipal housing company faced allegations of bribery in 2016. A black market for flats had already emerged the year before, as the waiting lists for social housing made people wait for a year or more until they were offered an apartment, while the payment of up to 1000 EUR enabled people to sign a contract within a few days (Leipziger Volkszeitung, 2016).

Altogether urban policies have to negotiate along a thin line between addressing the specific needs and con- straints of people with an asylum background and othering/discriminating them through special concepts that show little or no conceptual coherence with other urban policies and the integrated urban planning perspective, as the new integrative master plan shows (Stadt Leipzig, 2018a). On the one hand, asylum seekers represent a group with a certain residence status, a temporally limited perspective to stay, language barriers, and social and economic opportunities. Thus, there are certain needs and constraints which are typical for their situation, even though the individual situation might differ widely. Many of those face the possible or actual experience with forms of racism and discrimination. On the other hand, it can be discussed as a form of othering if issues such as (decentralized) housing, that are closely interconnected with the housing market and its dynamics are handled in a special accommodation concept, while Leipzig's accommodation concept rarely acknowledges this group (asylum seekers) as a demand group. So, any solution represents a more or less successful compromise between those poles.

Summarizing, we can determine the GoA and especially the issue of housing as a contested field mainly with a perspective on involved actors and actors' interests. We call it "contested" for several reasons: When looking at the municipality, first, asylum-related policy fields have interrelations with policy fields such as urban planning, housing, and social welfare. Second, the emerging questions regarding the reception of refugees urge different units of municipal administration to find ways of collaboration. Third, with their different foci and interests, they have to find new forms of coordination. When looking at the public sphere and civil society, new conflicts of how to organize the housing and co-existence of locals and refugees become obvious. Fourth, and most contested, is Leipzig's housing market (which is in line with the result of other multi-case-study analyses such as BBSR, 2017). Here, the reduction of social housing over the last decades due to privatization led to municipalities having a very small leeway for influencing and controlling the housing market. The resulting insufficient supply of accommodation possibilities and affordable flats poses a great challenge with regard to the increased needs of asylum seekers.

\section{Conclusions}

The article has analyzed how the accommodation and housing of asylum seekers are organized and governed in German cities, using the example of the city of Leipzig. In particular, it has focused on the housing of asylum seekers as a new policy field for urban planning at the local scale and has asked how far it can be described as a contested field that is characterized by many challenges and interest conflicts between the actors involved. We adopted the perspective of a local GoA as a specification of urban governance with regard to the reception of asylum seekers, as the evolved socio-spatial arrangements 
are place-specific and temporal, shaped and reproduced by the interplay and interdependencies of the local actors, as we described in the previous chapter. Accommodation and housing for asylum seekers became a new field of urban policy over the last years, and the specific situation in 2015 led to the establishment of new governance arrangements and institutions such as the interdepartmental working group Asylum or the Contact Point Housing and made the landscape of stakeholders more complex and variegated. The empirical analysis showed, furthermore, that housing of asylum seekers is a contested field indeed, for several reasons. First, since the increasingly tight housing market offers little availability for this demanding group. Second, since the governance of housing is characterized by many actors and diverse interest conflicts between them, in a situation where a couple of new collaborations and governance arrangements had to be established on short notice. Third, since there is discrimination and racism, which aggravate the situation for asylum seekers to find appropriate housing. While the "chaotic" conditions of 2015 are no longer a reality, the housing of asylum seekers and the social housing market, in general, remain a challenge for urban planning and policy-making in Leipzig. This fact clearly indicates that the issue is much more complex and of long-term relevance than the sheer problem of the "number" of refugees arriving in 2015. The example of GoA in Leipzig shows the challenges and problems of dealing with a new policy field and integrating it into more general governance arrangements.

With regard to its accommodation concept, Leipzig can be seen as a pioneer of a progressive municipal asylum policy in Germany and Europe. This concept was politically controversial from the beginning, and the conditions of housing as part of the GoA turned out to be a contested field, as analyzed in this article. The so-called concept of decentralized accommodation did not work properly from the outset due to inadequate planning and implementation; there has been a divergence between claim and reality from the beginning. In 2015-2016 when the number of asylum seekers in Leipzig peaked after a steady increase since 2009, the accommodation concept could not be implemented because the housing market in Leipzig was strained and it was practically impossible for asylum seekers to find appropriate affordable housing. Although the city reacted to the tense housing market with a new housing policy concept for Leipzig, refugees, and asylum seekers, and their supply of housing did not appear in it sufficiently. The planning concepts and the relevant policy areas have not been linked; refugees and asylum seekers play no role in municipal planning documents. Rather, a specific governance structure has been established to care for their accommodation, but independently from the system due to which the accommodation concept works. Civil society initiatives were included in the arrangements established in 2015 to provide housing for asylum seekers but they were soon overstrained with this task.
All in all, the GoA can be embedded in a highly dynamic field and its arrangements face a certain temporality. From the time of its drafting until now, the implementation of the accommodation concept ran after the real developments such as the number of arrivals or the changes in the housing market. After all, the decisions about concepts, policies, and available financial means related to the design of the GoA are abundant on political majorities in the City Council. The developments and reactions in 2015 and beyond brought political-administrative stakeholders and civil society actors to the limits of feasibility. Currently, no political efforts are recognizable that would substantially change this situation.

\section{Acknowledgments}

We would like to thank the peer-reviewers and editor of the journal for their comments, which significantly helped improve the article.

\section{Conflict of Interests}

The authors declare no conflict of interests.

\section{References}

Ataç, I., Kron, S., Schilliger, S., Schwiertz, H., \& Stierl, M. (2015). Struggles of migration as in-/visible politics. Introduction. Movements. Journal for Critical Migration and Border Regime Studies, 1(2). Retrieved from movements-journal.org/issues/02.kaempfe/01.ata\% C3\%A7, kron,schilliger,schwiertz,stierl--einleitung en.html

Asylum Information Database. (2015). Common asylum system at a turning point: Refugees caught in Europe's solidarity crisis (Annual Report 2014-2015). Retrieved from www.asylumineurope.org/sites/de fault/files/shadow-reports/aida_annualreport_2014 -2015_0.pdf

Aumüller, J. (2018). Die kommunale Integration von Flüchtlingen [The municipal integration of refugees]. In F. Gesemann \& R. Roth (Eds.). Handbuch Lokale Integrationspolitik [Handbook local integration policy] (pp. 173-198). Wiesbaden: Springer Fachmedien.

Aumüller, J. (2015): Teil 1: Rahmenbedingungen der Flüchtlingsaufnahme und ihre Umsetzung in den Kommunen [Frameworks of refugee reception and its Implementation on the municipal level]. In J. Aumüller, P. Daphi, \& C. Biesenkamp (Eds.), Die Aufnahme von Flüchtlingen in den Bundesländern und Kommunen [The reception of refugees in federal states and municipalities] (pp. 19-120). Stuttgart: Robert Bosch Stiftung. Retrieved from http://www. bosch-stiftung.de/content/language1/downloads/ Studie_Aufnahme_Fluechtlinge_2015.pdf

Budnik, M., Grossmann, K., Haase, A., Haid, C., Hedke, C., Kullmann, K., \& Wolff, M. (2016). DIVERCITIES. Living 
with urban diversity: The case of Leipzig, Germany. Utrecht: Utrecht University, Faculty of Geosciences.

Bundesinstitut für Bau-, Stadt- und Raumforschung. (2017). Integration von Flüchtlingen in den regulären Wohnungsmarkt [Integration of refugees into the regular housing market]. BBSR: Federal Institute for Research on Building, Urban Affairs and Spatial Development. Retrieved from www.bbsr.bund. de/BBSR/DE/Veroeffentlichungen/BBSROnline/2017 /bbsr-online-21-2017.html?nn=439538

Eckardt, F. (2018). Anti-Asyl-Proteste als NIMBYPhänomen [Anti-asylum protests as a NIMBY phenomenon]. In F. Eckardt (Ed.), Ungeliebte Nachbarn? Anti-Asyl-Proteste in Thüringen [Unloved neighbors? Anti-asylum protests in Thuringia] (pp. 45-56). Bielefeld: transcript.

El-Kayed, N., \& Hamann, U. (2018). Refugees' access to housing and residency in German cities: Internal border regimes and their local variations. Social Inclusion, 6(1), 135-146.

European Commission. (2018). Immigrant housing in Europe: Overview. EC.Europa. Retrieved from ec. europa.eu/migrant-integration/intdossier/ewsi-ana lysis-immigrant-housing-in-europe

European Migration Network. (2014). The organisation of reception facilities for asylum seekers in different member states (Synthesis Report). Brussels: European Migration Network. Retrieved from emn.ie/ files/p_20140207073231EMN\%20Organisation\%20of \%20Reception\%20Facilities\%20Synthesis\%20Report. pdf

Federal Anti-Discrimination Agency. (2016). Risks of discrimination for refugees in Germany. Antidiskriminierungsstelle. Retrieved from www.antidiskrimi nierungsstelle.de/SharedDocs/Downloads/DE/publi kationen/Factsheets/factsheet_engl_Diskriminierungs risiken_fuer_Gefluechtete_in_Dtschl.pdf?__blob= publicationFile\& $v=3$

Fontanari, E. (2015). Confined to the threshold. The experiences of asylum seekers in Germany. City, 5(19), 714-726.

Gesemann, F., \& Roth, R. (2016). Kommunale Flüchtlingsund Integrationspolitik. Ergebnisse einer Umfrage in Städten, Landkreisen und Gemeinden [Municipal refugee and integration policy. Results of a survey in cities, districts and municipalities]. Berlin: DESI.

Grossmann, K., Arndt, T., Haase, A., Rink, D., \& Steinführer, A. (2015). The influence of housing oversupply on residential segregation. Exploring the postsocialist city of Leipzig. Urban Geography, 36(4), 550-577.

Hallenberg, B. (2017). Wo steht die Integration der Geflüchteten im Herbst 2017? Zuwanderung, räumliche Verteilung und Wohnungsversorgung [What is the state of affairs regarding the integration of refugees in autumn 2017? Migration, spatial distribution and housing provision](vhw werkSTADT 15/2017). Berlin: Vhw-Bundesverband für Wohnen und Stadtentwicklung.

Helbig, M., \& Jähnen, S. (2018). Trends und Analysen der Segregation in 74 deutschen Städten [Trends and analyses of segregation in 74 German cities] (WZB Discussion Paper 2018-001). Berlin: WZB Berlin Social Science Center.

Hinger, S. (2016). Asylum in Germany: The making of the crisis and the role of civil society. Human Geography, 9(2), 78-88.

Hinger, S., Schäfer, P., \& Pott, A. (2016). The local production of Asylum. Journal of Refugee Studies, 29(4), 440-463.

International Federation for Housing and Planning. (2016). Housing Refugees Report. London: IFHP. Retrieved from www.ifhp.org/sites/default/files/ staff/IFHP\%20Housing\%2ORefugees\%20Report\%20\%20final.pdf

Karakayali, S., \& Kleist, J. O. (2016). Volunteers and asylum seekers. Forced Migration Review, 51, 65-67.

Kasparek, B., \& Speer, M. (2015). Of hope. Hungary and the long summer of migration. Border Monitoring. Retrieved from bordermonitoring.eu/ungarn/ 2015/09/of-hope-en

Leipziger Internetzeitung. (2017, December 15). Juliane Nagel (Linke): "Wohnfähigkeitsprüfung" in Leipzig zurückgenommen ["Test on ability to housing" in Leipzig has been withdrawn]. Leipziger Internetzeitung. Retrieved from www.l-iz.de/melder/wortmel der/2017/12/Juliane-Nagel-Linke-\%E2\%80\%9EWohn faehigkeitspruefung\%E2\%80\%9C-in-Leipzig-zurueck genommen-200484

Leipziger Volkszeitung. (2016, September 1). Bericht: Schmiergeld für Flüchtlingswohnungen in LeipzigLWB angeblich verstrickt [Report: Bribe money for refugee housing in Leipzig. LWB supposedly involved]. Leipziger Internetzeitung. Retrieved from www.lvz. de/Leipzig/Lokales/Bericht-Schmiergeld-fuer-Fluecht lingswohnungen-in-Leipzig-LWB-angeblich-verstrickt

Mierswa, K. (2016). Reception conditions of asylum seekers in the European Union: Is the EU fulfilling its obligations? Paper presented at the ISA HR NYC Conference on Human Rights in an Age of Ambiguity, Fordham University, New York. Retrieved from web. isanet.org/Web/Conferences/HR2016-NYC/Archive/ 55d9403d-86cf-4d32-a6c2-ef458294d3dd.pdf

Mitchell, D. (2002). Cultural landscapes: The dialectical landscape. Recent landscape research in human geography. Progress in Human Geography, 26(3), 381-389.

Philipps, A., \& Rink, D. (2009). Zuwanderung und Integrationspolitik in einer schrumpfenden Stadt: Das Beispiel Leipzig [Immigration and integration policy in a shrinking city: The example of Leipzig]. In F. Gesemann \& R. Roth (Eds.), Lokale Integrationspolitik in der Einwanderungsgesellschaft [Local integration policy in the immigration society] (pp. 399-413). Wiesbaden: VS Verlag für Sozialwissenschaften.

Rink, D., Schneider, A., \& Haase, A. (2018). Das 
preiswerte Wohnsegment in Leipzig [The low-cost residential sector in Leipzig]. Helmholtz Centre for Environmental Research-UFZ. Unpublished Manuscript.

Sächsische Staatskanzlei. (2018). Verteilung von Flüchtlingen [Distribution of refugees]. Asylinfo Sachsen. Retrieved from www.asylinfo.sachsen.de/fragen -und-antworten-zum-thema-asyl.html?_cp=\%7B\%7D

Schammann, H. (2015). Rette sich, wer kann? Flüchtlingspolitik im Föderalismus. Aus Politik und Zeitgeschichte, 25, 26-31.

Stadt Leipzig. (2010). Beschluss der Ratsversammlung. Betreff: Konzept dezentrale Unterbringung [Decision of the town council. Subject: Concept for decentralized accommodation] (RBV-404/10). Leipzig.de. Retrieved from https://notes.leipzig.de/ appl/laura/wp5/kais02.nsf/docid/76316559F0B12292 C1257751002F56F3/\$FILE/V-rb-404-ausfertigung.pdf

Stadt Leipzig. (2012). Teil 1: Konzept "Wohnen für Berechtigte nach dem Asylbewerberleistungsgesetz in Leipzig" Erarbeitet: Sozialamt. Leipzig.de. Retrieved from https://notes.leipzig.de/appl/laura/ wp5/kais02.nsf/docid/OB185DEEF2854883C125795A 002E9AC1/\$FILE/V-ds-1904-nf-anlage.pdf

Stadt Leipzig. (2013). Fortschreibung des Konzeptes "Wohnen für Berechtigte nach dem Asylbewerberleistungsgesetz in Leipzig" [Update of the concept "Housing for recipients of the Benefits for Asylum Seekers Act in Leipzig"]. Leipzig: Stadt Leipzig.

Stadt Leipzig. (2015). Wohnungspolitisches Konzept. Fortschreibung 2015. Retrieved from www.leipzig. de/fileadmin/mediendatenbank/leipzig-de/Stadt/02.6 _Dez6_Stadtentwicklung_Bau/61_Stadtplanungsamt /Stadtentwicklung/Leipzig_weiter_denken/Wohnen /Wohnungspolitisches_Konzept.pdf

Stadt Leipzig. (2018a). Aktueller Sachstand und weitere Planungen für die Unterbringung von Geflüchteten in der Zuständigkeit der Stadt Leipzig-Stand [State of affairs and further planning regarding the accommodation of refugees under the responsibility of the City of Leipzig] (Neufassung Nr. VI-Ifo-05666NF-01). Retrieved from ratsinfo.leipzig.de/bi/ tmp/tmp/4508103664477250/64477250/01390229/ 29.pdf

Stadt Leipzig. (2018b). Leipzig-Informationssystem [Leipzig Information System]. Leipzig.de. Retrieved from statistik.leipzig.de

Stadt Leipzig. (2018d). Kosten der Unterkunft im Arbeitslosengeld II [Housing costs according to unemployment benefits, type II]. Leipzig.de. Retrieved from leipzig.de/wirtschaft-und-wissenschaft/arbeiten-inleipzig/jobcenter/leistungen-fuer-arbeitsuchende/ kosten-der-unterkunft-im-arbeitslosengeld-ii

Statistisches Bundesamt. (2018a). Asylbewerberleistungsgesetz. Empfängerinnen und Empfänger nach Bundesländern. Regelleistungen insgesamt nach Bundesländern und Art der Unterbringung am 31.12.2017 [Asylum Benefits Act. Recipients according to federal state. Standard benefits according to federal state and type of accommodation, 31.12.2017]. Destatis. Retrieved from www.destatis. de/DE/ZahlenFakten/GesellschaftStaat/Soziales/Sozi alleistungen/Asylbewerberleistungen/Tabellen/Tabel len_EmfaengerBL.html

Statistisches Bundesamt. (2018b). Bevölkerung nach Migrationshintergrund und Bundesländern [Population according to migrant background and federal states]. Destatis. Retrieved from www.destatis.de/ DE/Methoden/Zensus_/Tabellen/MHG_1_Laender Gemeinden.html

Swyngedouw, E. (2005). Governance Innovation and the Citizen: The Janus face of governance-beyond-thestate. Human Geography, 42(11), 1991-2006.

Wendel, K. (2014). Unterbringung von Flüchtlingen in Deutschland. Regelungen und Praxis der Bundesländer im Vergleich [Accommodation of refugees in Germany. Regulations and practical application of federal states in comparison]. Frankfurt am Main: Pro Asyl.

\section{About the Authors}

Franziska Werner studied Sociology and Cultural Sciences with a focus on Urban Sociology at the University of Leipzig, Germa, and the University of Salamanca, Spain. Since 2013, she has worked at the Chair of Urban Studies and Social Research at Bauhaus-Universität Weimar, Germany, as an Assistant Researcher and teacher. Her research interest is in urban studies, with a particular focus in migration and refugee studies and qualitative research methods. Since 2017, she has been a PhD student at the Hafen City University Hamburg, Germany. Her PhD project is on the relation between refugee women and public space.

Annegret Haase is an Urban Sociologist and works at the Helmholtz Centre for Environmental Research (UFZ) in Leipzig, Germany, in the Department of Urban and Environmental Sociology. Her research foci are sustainable urban development, urban trajectories such as shrinkage and reurbanization, socio-spatial differentiation at the level of cities and neighborhoods, migration and urban diversity, social-ecological transformation and goal conflicts in cities, housing market development, urban governance, e and participatory neighborhood development. Another focus is urban theory and concept and, in particular, the shrinking and post-socialist city. She has been involved in many nationally funded (BMBF, VW) and internationally funded (EU 5\&7FP, H2020, GPSF) projects and has a strong adherence to interdisciplinary and transdisciplinary research. 
Nona Renner studied Cultural Sciences with a focus on Urban Sociology at the University of Leipzig and the Eötvös Loránd University in Budapest. Since 2017 she has worked as a Research Assistant at the Mercator Forum Migration and Democracy at the University of Technology Dresden. Her research interests are on urban migration and refugees' studies as well as qualitative research methods.

Dieter Rink studied Cultural Sciences and Philosophy at the Karl-Marx-University Leipzig. From 1991 to 1994, he worked at the Science Centre Berlin. In 1994, he became a Research Assistant at the UFZ. Now he is a Senior Researcher and Deputy Head of the Department of Urban and Environmental Sociology at the Helmholtz Centre for Environmental Research, additionally he is an Honorary Professor for Urban Sociology at the University of Leipzig, Institute for Cultural Studies. His main research fields are sustainable urban development, urban governance and social movements, urban nature and urban ecology, housing, and housing policy. He has been member and coordinator of various national and international research projects and numerous publications on the above-mentioned issues. His research is strongly interdisciplinary oriented and includes international comparative studies.

Malena Rottwinkel works as a Research Assistant at the Department of Urban Studies and Social Research at BauhausUniversität Weimar. She studied European studies at Maastricht University, political science at Bogazici University and sustainable development at Leipzig University, Karl-Franzens-University Graz and Stellenbosch University. Within her studies, she specialized in the field of critical geography and urban sociology and wrote her master thesis on spatial perceptions of refugees living in centralized and decentralized accommodation in Leipzig.

Anika Schmidt studied social and economic Geography of urban areas at the University of Leipzig. Since 2018, she has worked as a Researcher at the Department of Urban and Environmental Sociology at the Helmholtz Centre for Environmental Research (UFZ) in Leipzig. Her current research interests focus on the intersections of urban and migration studies with a focus on the neighborhood level as well as cooperation and arrangements between state and non-state actors. 